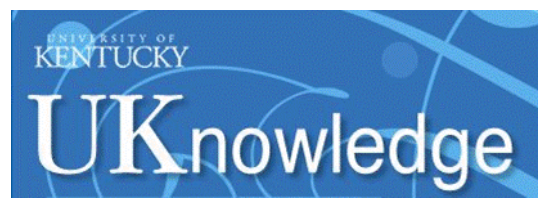

University of Kentucky

UKnowledge

$5-16-2018$

\title{
Spectroscopy and Formation of Lanthanum-Hydrocarbon Radicals Formed by Association and Carbon-Carbon Bond Cleavage of Isoprene
}

\author{
Wenjin Cao \\ University of Kentucky, wj.cao0707@uky.edu \\ Dilkrushi Hewage \\ University of Kentucky, dche223@uky.edu \\ Dong-Sheng Yang \\ University of Kentucky, Dong-Sheng.Yang@uky.edu
}

Follow this and additional works at: https://uknowledge.uky.edu/chemistry_facpub

Part of the Biological and Chemical Physics Commons, Chemistry Commons, and the Plasma and Beam Physics Commons

Right click to open a feedback form in a new tab to let us know how this document benefits you.

\section{Repository Citation}

Cao, Wenjin; Hewage, Dilkrushi; and Yang, Dong-Sheng, "Spectroscopy and Formation of LanthanumHydrocarbon Radicals Formed by Association and Carbon-Carbon Bond Cleavage of Isoprene" (2018). Chemistry Faculty Publications. 119.

https://uknowledge.uky.edu/chemistry_facpub/119

This Article is brought to you for free and open access by the Chemistry at UKnowledge. It has been accepted for inclusion in Chemistry Faculty Publications by an authorized administrator of UKnowledge. For more information, please contact UKnowledge@lsv.uky.edu. 
Spectroscopy and Formation of Lanthanum-Hydrocarbon Radicals Formed by Association and Carbon-Carbon Bond Cleavage of Isoprene

\author{
Digital Object Identifier (DOI) \\ https://doi.org/10.1063/1.5026899 \\ Notes/Citation Information \\ Published in The Journal of Chemical Physics, v. 148, issue 19, 194302, p. 1-9.
}

This article may be downloaded for personal use only. Any other use requires prior permission of the author and AIP Publishing.

The following article appeared in The Journal of Chemical Physics, v. 148, issue 19, 194302, p. 1-9 and may be found at https://doi.org/10.1063/1.5026899. 


\section{Spectroscopy and formation of lanthanum-hydrocarbon radicals formed by association and carbon-carbon bond cleavage of isoprene}

Wenjin Cao, Dilrukshi Hewage, and Dong-Sheng Yang

Citation: J. Chem. Phys. 148, 194302 (2018); doi: 10.1063/1.5026899

View online: https://doi.org/10.1063/1.5026899

View Table of Contents: http://aip.scitation.org/toc/jcp/148/19

Published by the American Institute of Physics

\section{Articles you may be interested in}

Spectroscopy and formation of lanthanum-hydrocarbon radicals formed by $\mathrm{C}-\mathrm{H}$ and $\mathrm{C}-\mathrm{C}$ bond activation of 1-pentene and 2-pentene

The Journal of Chemical Physics 149, 034303 (2018); 10.1063/1.5022771

Photofragment imaging and electronic spectroscopy of $\mathrm{Al}_{2}{ }^{+}$

The Journal of Chemical Physics 148, 214308 (2018); 10.1063/1.5034353

Dissociation dynamics of 3- and 4-nitrotoluene radical cations: Coherently driven $\mathrm{C}-\mathrm{NO}_{2}$ bond homolysis

The Journal of Chemical Physics 148, 134305 (2018); 10.1063/1.5024892

Time-resolved photoelectron spectroscopy of adenosine and adenosine monophosphate photodeactivation dynamics in water microjets

The Journal of Chemical Physics 148, 194303 (2018); 10.1063/1.5027258

Spectroscopy and formation of lanthanum-hydrocarbon radicals formed by $\mathrm{C}-\mathrm{C}$ bond cleavage and coupling of propene

The Journal of Chemical Physics 146, 184304 (2017); 10.1063/1.4982949

Lanthanum-mediated dehydrogenation of 1- and 2-butynes: Spectroscopy and formation of $\mathrm{La}\left(\mathrm{C}_{4} \mathrm{H}_{4}\right)$

isomers

The Journal of Chemical Physics 147, 064303 (2017); 10.1063/1.4997567

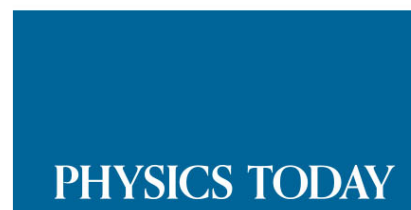

WHITEPAPERS
ADVANCED LIGHT CURE ADHESIVES

Take a closer look at what these environmentally friendly adhesive systems can do

\section{READ NOW}

PRESENTED BY

Q MASTERBOND 


\title{
Spectroscopy and formation of lanthanum-hydrocarbon radicals formed by association and carbon-carbon bond cleavage of isoprene
}

\author{
Wenjin Cao, Dilrukshi Hewage, and Dong-Sheng Yang ${ }^{\text {a) }}$ \\ Department of Chemistry, University of Kentucky, Lexington, Kentucky 40506-0055, USA
}

(Received 25 February 2018; accepted 27 April 2018; published online 16 May 2018)

\begin{abstract}
$\mathrm{La}$ atom reaction with isoprene is carried out in a laser-vaporization molecular beam source. The reaction yields an adduct as the major product and $\mathrm{C}-\mathrm{C}$ cleaved and dehydrogenated species as the minor ones. $\mathrm{La}\left(\mathrm{C}_{5} \mathrm{H}_{8}\right), \mathrm{La}\left(\mathrm{C}_{2} \mathrm{H}_{2}\right)$, and $\mathrm{La}\left(\mathrm{C}_{3} \mathrm{H}_{4}\right)$ are characterized with mass-analyzed threshold ionization (MATI) spectroscopy and quantum chemical computations. The MATI spectra of all three species exhibit a strong origin band and several weak vibronic bands corresponding to La-ligand stretch and ligand-based bend excitations. $\mathrm{La}\left(\mathrm{C}_{5} \mathrm{H}_{8}\right)$ is a five-membered metallacycle, whereas $\mathrm{La}\left(\mathrm{C}_{2} \mathrm{H}_{2}\right)$ and $\mathrm{La}\left(\mathrm{C}_{3} \mathrm{H}_{4}\right)$ are three-membered rings. All three metallacycles prefer a doublet ground state with a La $6 s^{1}$-based valence electron configuration and a singlet ion. The five-membered metallacycle is formed through $\mathrm{La}$ addition and isoprene isomerization, whereas the two three-membered rings are produced by La addition and insertion, hydrogen migration, and carbon-carbon bond cleavage. Published by AIP Publishing. https://doi.org/10.1063/1.5026899
\end{abstract}

\section{INTRODUCTION}

Hydrocarbon compounds are ubiquitous in nature and the most abundant, low-cost feedstock for functionalized organic chemicals yet many of which are too inert to participate in chemical reactions under mild conditions. Metal activation helps us to mitigate this problem by stimulating inert hydrocarbons to react with other molecules. To better understand how metal centers activate $\mathrm{C}-\mathrm{H} / \mathrm{C}$ bonds, spectroscopy of transition metal-hydrocarbon species formed in gas phase reactions has recently attracted considerable attention. Metal ion-hydrocarbon species are largely investigated by infrared or ultraviolet-visible photodissociation or photoelectron spectroscopy, ${ }^{1-34}$ whereas metal atom-hydrocarbon radicals are mainly studied by resonant two-photon ionization and dispersed fluorescence, ${ }^{35-38}$ Fourier transform microwave, ${ }^{39}$ and mass analyzed threshold ionization (MATI) spectroscopy. ${ }^{40-48}$ Spectroscopic measurements probe state specific energies and structures of short-lived species, which are vital for gaining insight into reaction mechanisms and electronic and structural characteristics for efficient bond activation at metal centers. Such measurements can also be used to test electronic structure calculations, where computations are complicated by possibly multiple low-energy isomers of each metal-containing species and high-density of low-lying electronic states or spin-orbit levels of each isomer. On the other hand, spectroscopic measurements of transition metal-hydrocarbon species formed by the $\mathrm{C}-\mathrm{H}$ or $\mathrm{C}-\mathrm{C}$ bond activation of hydrocarbon compounds encounter substantial challenges because such species are produced with a low number density and often in an open-shell electronic state. We have recently reported the MATI spectroscopy and formation of the metal-hydrocarbon

a)Author to whom correspondence should be addressed: dyang0@uky.edu radicals produced by the lanthanide-mediated $\mathrm{C}-\mathrm{C}$ or $\mathrm{C}-\mathrm{H}$ bond activation of several small alkenes and alkynes. ${ }^{40-48}$ Our studies demonstrate that the combination of the MATI spectroscopic measurements with electronic structure calculations is a powerful approach to investigate transient metal-hydrocarbon species.

Isoprene (2-methyl-1,3-butadiene) is one of the most abundant volatile organic compounds in the troposphere. Its emission affects the aerosol formation and contributes to the formation of tropospheric ozone in the presence of nitric oxides. ${ }^{40}$ Its industrial applications are largely for polydiene production. The most effective method for the precise control of polydienes is coordination-insertion polymerization accomplished by single-site transition metal catalysts. ${ }^{49}$ Although isoprene reactions with metal ions or atoms in the gas phase have rarely been reported, metal ion reactions with its parent molecule, 1,3-butadiene, have been investigated with mass spectrometry based methods. Bohme and co-workers observed sequential additions of the butadiene to $\mathrm{Fe}^{+}$(up to four ligands) using a selected-ion flow tube technique. ${ }^{50}$ Freiser and co-workers detected $\mathrm{M}^{+}(1,3$-butadiene) adduct as the only product for $\mathrm{M}=\mathrm{Ni}$ but both $\mathrm{M}^{+}(1,3$-butadiene $)$ and $\mathrm{M}^{+}\left(\mathrm{C}_{4} \mathrm{H}_{4}\right)$ corresponding to a $\mathrm{H}_{2}$ loss for $\mathrm{M}=\mathrm{Fe}$ and Co using Fourier transform ion cyclotron resonance (FTICR) mass spectrometry. ${ }^{51}$ In contrast to the late transition metal ions, Ohanessian and co-workers observed, also with FTICR, $\mathrm{W}^{+}\left(\mathrm{C}_{4} \mathrm{H}_{4}\right)$ as the major product, with minor amounts of $\mathrm{W}^{+}\left(\mathrm{C}_{2} \mathrm{H}_{2}\right)$ and of $\mathrm{W}^{+}\left(\mathrm{C}_{3} \mathrm{H}_{2}\right){ }^{52}$ In reactions with transition metal oxide ions, Castleman and co-workers observed using a triple quadrupole mass spectrometer system that tantalum oxide cluster ions cleaved the butadiene to give $\mathrm{Ta}_{\mathrm{x}} \mathrm{O}_{\mathrm{y}}{ }^{+}\left(\mathrm{C}_{2} \mathrm{H}_{4}\right)$ as the major reaction, ${ }^{53,54}$ whereas vanadium oxide cluster ion reactions yielded $\mathrm{V}_{\mathrm{x}} \mathrm{O}_{\mathrm{y}}{ }^{+}\left(\mathrm{C}_{4} \mathrm{H}_{6}\right)$ as the major products, with minor amounts of $\mathrm{V}_{\mathrm{x}} \mathrm{O}_{\mathrm{y}}{ }^{+}\left(\mathrm{C}_{4} \mathrm{H}_{4}\right)$ and $\mathrm{V}_{\mathrm{x}} \mathrm{O}_{\mathrm{y}}{ }^{+}\left(\mathrm{C}_{2} \mathrm{H}_{3}\right){ }^{55}$ 1,3-butadiene reactions with neutral vanadium oxide clusters have been studied 
by Bernstein, $\mathrm{He}$, and co-workers, where $\mathrm{V}_{\mathrm{x}} \mathrm{O}_{\mathrm{y}}\left(\mathrm{C}_{3} \mathrm{H}_{4}\right)$ and $\mathrm{V}_{\mathrm{x}} \mathrm{O}_{\mathrm{y}}\left(\mathrm{C}_{4} \mathrm{H}_{6}\right)$ were detected through soft $\mathrm{x}$-ray photoionization. ${ }^{56}$ In all of the aforementioned studies, no spectroscopic measurements were reported.

In a very recent study, we reported spectroscopic characterization of nonconcerted [4+2] cycloaddition of 1,3butadiene with lanthanacyclopropene $[\mathrm{La}(\mathrm{CH}=\mathrm{CH})]$ to form $\mathrm{La}$ (benzene).$^{44}$ Lanthanacyclopropene is an intermediate generated by the primary reaction between La and 1,3-butadiene, and computational prediction suggests that the formation of this intermediate involves $\mathrm{La}$ addition, 1,3-butadiene isomerization, 1,3 or 4,2-H migration, and $\mathrm{C} 2-\mathrm{C} 3$ bond cracking. To test the computational prediction, we carried out a MATI spectroscopic study of the metal radicals formed by the $\mathrm{La}+$ isoprene reaction. Because the $\mathrm{H}$ atom on the $\mathrm{C} 2$ position of 1,3-butadiene is replaced by a methyl group in isoprene, a 1,3$\mathrm{H}$ migration followed by the cleavage of the isoprene $\mathrm{C} 2-\mathrm{C} 3$ single bond is expected to form a methyl-substitute lanthanacyclopropene $\left[\mathrm{La}\left(\mathrm{CH}=\mathrm{CCH}_{3}\right)\right]+$ ethylene, whereas a $4,2-\mathrm{H}$ migration followed by the $\mathrm{C} 2-\mathrm{C} 3$ bond cracking should produce lanthanacyclopropene $[\mathrm{La}(\mathrm{CH}=\mathrm{CH})]+$ propene. Competing with the 1,3- $\mathrm{H}$ migration, a $\mathrm{H}$ atom in the methyl group could also migrate to $\mathrm{C} 3$ to form $\mathrm{La}\left[\mathrm{H}_{2} \mathrm{CC}\left(\mathrm{CH}_{2}\right) \mathrm{CH}_{2} \mathrm{CH}_{2}\right]$ which then may decompose to $\mathrm{La}\left(\mathrm{CH}_{2}=\mathrm{C}=\mathrm{CH}_{2}\right)+$ ethylene or $\mathrm{La}\left(\mathrm{CH}_{2} \mathrm{CH}_{2}\right)+$ allene through the cleavage of the $\mathrm{C} 2-\mathrm{C} 3$ single bond. We report here the MATI spectroscopy and formation of La-hydrocarbon radicals formed by molecular addition and $\mathrm{C}-\mathrm{C}$ bond cleavage. In this work, we observe both $\mathrm{La}(\mathrm{CH}=\mathrm{CH})$ and $\mathrm{La}\left(\mathrm{CH}=\mathrm{CCH}_{3}\right)$, confirming the previously proposed pathway for the formation of $\mathrm{La}(\mathrm{CH}=\mathrm{CH})$ from the $\mathrm{La}+1$,3-butadiene reaction. On the other hand, we detect no traces of $\mathrm{La}\left[\mathrm{H}_{2} \mathrm{CC}\left(\mathrm{CH}_{2}\right) \mathrm{CH}_{2} \mathrm{CH}_{2}\right], \mathrm{La}\left(\mathrm{CH}_{2}=\mathrm{C}\right.$ $\left.=\mathrm{CH}_{2}\right)$, or $\mathrm{La}\left(\mathrm{CH}_{2} \mathrm{CH}_{2}\right)$, suggesting that a $\mathrm{H}$ migration from the methyl group of isoprene is insignificant in the $\mathrm{La}+$ isoprene reaction.

\section{EXPERIMENTAL AND COMPUTATIONAL METHODS}

\section{A. Experimental}

The metal-cluster beam instrument used in this work consists of reaction and spectroscopy vacuum chambers and was described in a previous publication. ${ }^{57}$ The La-isoprene reaction was carried out in a laser-ablation metal cluster beam source. La atoms were generated by pulsed laser (Nd:YAG, Continuum Minilite II, $532 \mathrm{~nm}, \sim 1.0 \mathrm{~mJ} / \mathrm{pulse}$ ) ablation of a La rod (99.9\%, Alfa Aesar) in the presence of a He (99.998\%, Scott Gross) carrier gas (40 psi) delivered by a home-made piezoelectric pulsed valve. Vapor of isoprene (boiling point $34{ }^{\circ} \mathrm{C}, 99 \%$, Aldrich) was introduced $3 \mathrm{~cm}$ downstream of the laser ablation point, from which $\mathrm{La}$ atoms, He gas, and the isoprene vapor entered into a collision tube $(2 \mathrm{~mm}$ diameter and $2 \mathrm{~cm}$ length) and were then expanded into the reaction chamber, collimated by a cone-shaped skimmer ( $2 \mathrm{~mm}$ inner diameter), and passed through a pair of deflection plates. Ionic species in the molecular beam that were formed by laser ablation were removed by an electric field $\left(100 \mathrm{~V} \mathrm{~cm}^{-1}\right)$ applied on the deflection plates, and neutral products were identified by photoionization time-of-flight (TOF) mass spectrometry.
Prior to the MATI measurements, photoionization efficiency spectra of La-hydrocarbon radicals were recorded to locate an approximate ionization threshold to guide MATI scans. In the MATI experiment, the La-hydrocarbon radicals were excited to high-lying Rydberg states in a single-photon process and ionized by a delayed pulsed electric field. The excitation laser was the frequency doubled output of a tunable dye laser (Lumonics HD-500), pumped by the third harmonic output (355 nm) of a Nd:YAG laser (Continuum Surelite II). The laser beam was collinear and counter-propagating with the molecular beam. The ionization pulsed field $\left(320 \mathrm{~V} \mathrm{~cm}^{-1}\right)$, which was also used for accelerating ions into the field free region, was generated by two high voltage pulse generators (DEI, PVX-4140) and delayed by $\sim 20 \mu$ s from the laser pulse by a delayed pulsed generator (SRS, DG645). A small dc field $\left(6.0 \mathrm{~V} \mathrm{~cm}^{-1}\right)$ from another power supply (GW INSTEK, GPS-30300) was used to separate the ions produced by direct photoionization from the MATI ions generated by the delayed field ionization. The MATI ion signals were obtained by scanning the tunable dye laser, detected by a dual microchannel plate detector, amplified by a preamplifier (SRS, SR445), visualized by a digital oscilloscope (Tektronix TDS 3012), and stored in a laboratory computer. Laser wavelengths were calibrated against titanium atomic transitions in the MATI spectral region, and the calibration was done after recording the MATI spectra. ${ }^{58}$ The Stark shift on the adiabatic ionization energy $(\triangle \mathrm{AIE})$ induced by the dc field $\left(\mathrm{E}_{\mathrm{f}}\right)$ was calculated using the relation of $\triangle \mathrm{AIE}=6.1 \mathrm{E}_{\mathrm{f}}^{1 / 2}$, where $\mathrm{E}_{\mathrm{f}}$ is in $\mathrm{V} \mathrm{cm}^{-1}$ and $\triangle \mathrm{AIE}$ is in $\mathrm{cm}^{-1} .59$

\section{B. Computational}

The density functional theory (DFT) method with Becke's three-parameter hybrid functional with the correlation functional of Lee, Yang, and Parr (B3LYP) was used to calculate the equilibrium geometries and vibrational frequencies of the La-hydrocarbon radicals and single charged positive ions. The basis sets used in these calculations were $6-311+G(d, p)$ for $\mathrm{C}$ and $\mathrm{H}$ and the Stuttgart/Dresden (SDD) effective-corepotential basis set with 28 -electron core for La. We have extensively used the DFT/B3LYP method and found that this method generally produced adequate results for spectral and structural assignments of organometallic radicals. ${ }^{40-42,44-48,60}$ No symmetry restrictions were imposed in initial geometry optimizations, but appropriate point groups were used in subsequent optimizations to help identify electronic symmetries. For each optimized stationary point, a vibrational analysis was performed to identify the nature of the stationary point (minimum or saddle point). In predicting reaction pathways, minima connected by a transition state were confirmed by intrinsic reaction coordinate calculations. To refine the energies of the electronic states, single-point energy calculations were carried out with the coupled cluster with single, double, and perturbative triple excitations $[\operatorname{CCSD}(\mathrm{T})]$ method. These calculations involve the third-order Douglas-Kroll-Hess scalar relativistic correction and are at the DFT/B3LYP optimized geometries. Basis sets used in the $\operatorname{CCSD}(\mathrm{T})$ calculations were cc-pVTZ-DK ${ }^{61,62}$ for $\mathrm{C}$ and $\mathrm{H}$ and cc-pVTZ-DK $3^{63}$ for La. The DFT calculations were performed with the Gaussian 09 
software package ${ }^{64}$ whereas the $\operatorname{CCSD}(\mathrm{T})$ calculations were carried out with MOLPRO 2010.1. ${ }^{65}$

To compare with the experimental MATI spectra, multidimensional Franck-Condon (FC) factors were calculated from the equilibrium geometries, harmonic vibrational frequencies, and normal coordinates of the neutral and ionized complexes. ${ }^{66}$ In these calculations, the recursion relations from Doktorov et al. ${ }^{67}$ were employed, and the Duschinsky effect ${ }^{68}$ was considered to account for a possible axis rotation from the neutral complex to the cation. Spectral simulations were obtained using the experimental linewidth and Lorentzian line shape. Transitions from excited vibrational levels of the neutral complex were considered by assuming thermal excitation at specific temperatures.

\section{RESULTS AND DISCUSSION}

\section{A. TOF mass spectrum and La-hydrocarbon species}

Figure 1 displays the TOF mass spectra of the La + isoprene reaction recorded with $235 \mathrm{~nm}$ photoionization. The spectra show La-hydrocarbon species corresponding $\mathrm{La}\left(\mathrm{C}_{\mathrm{n}} \mathrm{H}_{\mathrm{m}}\right)(\mathrm{n}=2,3,5$, and $7 ; \mathrm{m}=2,4,6$, and 8$)$. These species may be formed through following primary and secondary reactions:

$$
\begin{aligned}
\mathrm{La}+\mathrm{C}_{5} \mathrm{H}_{8} \longrightarrow \mathrm{La}\left(\mathrm{C}_{5} \mathrm{H}_{8}\right) \\
\longrightarrow \mathrm{La}\left(\mathrm{C}_{5} \mathrm{H}_{6}\right)+\mathrm{H}_{2} \\
\longrightarrow \mathrm{La}\left(\mathrm{C}_{2} \mathrm{H}_{2}\right)+\mathrm{C}_{3} \mathrm{H}_{6} \\
\mathrm{La}\left(\mathrm{C}_{3} \mathrm{H}_{4}\right)+\mathrm{C}_{2} \mathrm{H}_{4} \\
\mathrm{La}\left(\mathrm{C}_{2} \mathrm{H}_{2}\right)+\mathrm{C}_{5} \mathrm{H}_{8} \longrightarrow \mathrm{La}\left(\mathrm{C}_{7} \mathrm{H}_{8}\right)+\mathrm{H}_{2} .
\end{aligned}
$$

The primary reactions (1a)-(1d) include molecular association, dehydrogenation, and $\mathrm{C}-\mathrm{C}$ bond cleavage, whereas the secondary reaction (2) involves addition of a second

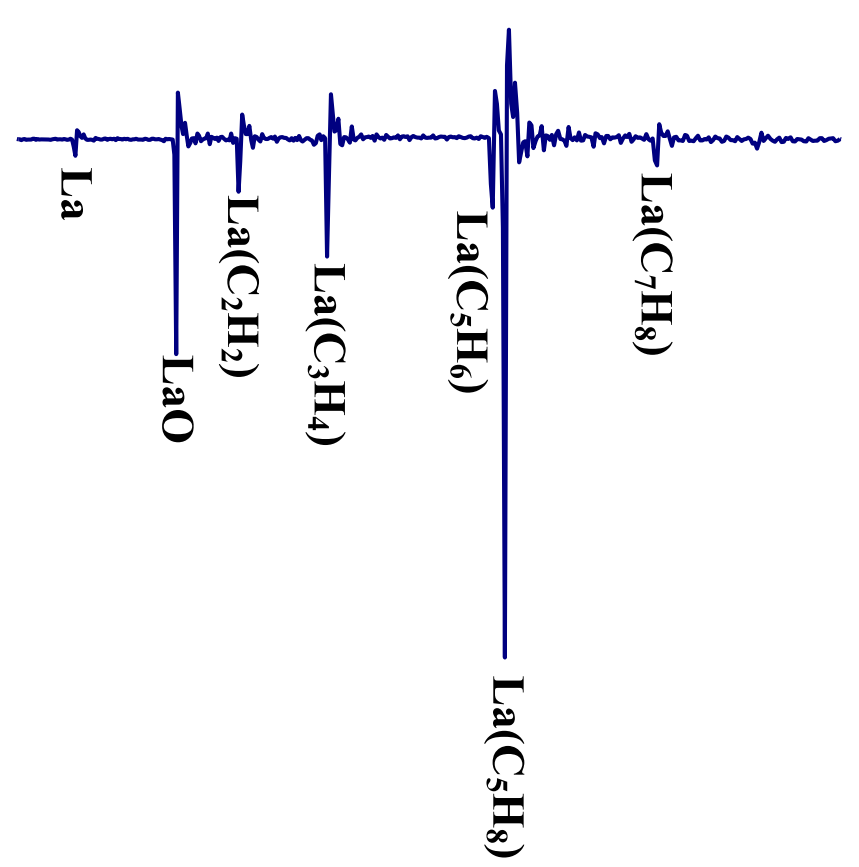

FIG. 1. TOF mass spectra of the $\mathrm{La}+$ isoprene reaction recorded with 235 $\mathrm{nm}$ laser ionization. isoprene molecule to one of the $\mathrm{C}-\mathrm{C}$ bond cleaved species $\mathrm{La}\left(\mathrm{C}_{2} \mathrm{H}_{2}\right)$ followed by a loss of $\mathrm{H}_{2}$. Although the reaction channels are similar to those observed for the $\mathrm{La}+1,3-$ butadiene reaction, ${ }^{44}$ branching ratios (BRs) of the metalhydrocarbon species formed in these channels are considerably different. In the isoprene reaction, the adduct $\mathrm{La}\left(\mathrm{C}_{5} \mathrm{H}_{8}\right)$ is by far the most predominant $(\mathrm{BR}=0.65)$, all other species from the primary reactions are relatively minor, and the only species from the secondary reaction is even less. By contrast, the $\mathrm{La}+1,3$-butadiene reactions yields $\mathrm{La}\left(\mathrm{C}_{2} \mathrm{H}_{2}\right)$ from the $\mathrm{C}-\mathrm{C}$ bond cleavage as the major product $(\mathrm{BR}=0.44)$ and other species from association, dehydrogenation, or secondary reactions as the minor ones. These observations suggest that the methyl substitution of a hydrogen atom in the $\mathrm{C} 2$ position of 1,3-butadiene decreases the hydrocarbon reactivity toward the La atom, especially the reaction channel of the $\mathrm{C}-\mathrm{C}$ bond cleavage. In addition to the metal-hydrocarbon species, a significant amount of $\mathrm{LaO}$ is observed. $\mathrm{LaO}$ could be formed by La reactions with oxygen that is present in the carrier gas as an impurity or by laser vaporization of La oxide impurity in the La rod. ${ }^{40-42,44-48}$ In the following paragraphs, we will focus on the spectroscopic and computational characterization of $\mathrm{La}\left(\mathrm{C}_{5} \mathrm{H}_{8}\right)$ formed through association and $\mathrm{La}\left(\mathrm{C}_{2} \mathrm{H}_{2}\right)$ and $\mathrm{La}\left(\mathrm{C}_{3} \mathrm{H}_{4}\right)$ formed through $\mathrm{C}-\mathrm{C}$ bond cracking.

\section{B. $\mathrm{La}\left(\mathrm{C}_{5} \mathrm{H}_{8}\right)$}

The MATI spectrum of $\mathrm{La}\left(\mathrm{C}_{5} \mathrm{H}_{8}\right)$ formed by the $\mathrm{La}+$ isoprene reaction [Fig. 2(a)] shows the strongest band at 39 007 (5) $\mathrm{cm}^{-1}, 352$ and $427 \mathrm{~cm}^{-1}$ progression with up to two vibrational quanta, and several weak bands $(100,235,295$, 474 , and $502 \mathrm{~cm}^{-1}$ ) at the higher energy side of the strongest band, and two additional weak bands ( 110 and $\left.342 \mathrm{~cm}^{-1}\right)$ at the lower energy side. Transitions marked with "** $1{ }^{-*} 3$ " are combination bands of $352 \mathrm{~cm}^{-1}$ with 235,295 , and $427 \mathrm{~cm}^{-1}$, respectively. The strongest band is easily assigned as the origin band, and its energy corresponds to the AIE of the metal-hydrocarbon radical. The strong origin band coupled with the short spectral profile indicates that the geometries of the neutral species and singly charged cation are similar, whereas the observation of numerous bands suggests that the metal-hydrocarbon radical must have a low molecular symmetry.

Two possible isomers of $\mathrm{La}\left(\mathrm{C}_{5} \mathrm{H}_{8}\right)$, Iso $\mathrm{A}\left(\mathrm{C}_{1}\right)$ and Iso B $\left(\mathrm{C}_{1}\right)$, are shown in Figs. 3(a) and 3(b), and their relative energies are listed in Table I. Iso B is a three-membered lanthanacycle with $\mathrm{La}$ binding with $\mathrm{C} 2$ and $\mathrm{C} 3$ atoms of the trans-isoprene. In the free trans-isoprene, the two $\mathrm{C}=\mathrm{C}$ bonds are predicted by DFT/B3LYP to be 1.338 and $1.342 \AA$ and the $\mathrm{C} 2-\mathrm{C} 3$ single bond is predicted to be $1.467 \AA$. Upon $\mathrm{La}$ addition, the two double bonds are extended to 1.439 and $1.437 \AA$, whereas the single bond is reduced to $1.410 \AA$ so that the three $\mathrm{CC}$ bonds become comparable. This metalmediated perturbation on the hydrocarbon structure can be understood from interactions between the frontier orbitals of the diene molecule and $5 \mathrm{~d}$ orbitals of the La atom. In a butadiene molecule, the four $\mathrm{C} p \pi$ orbitals of the highest occupied molecular orbital (HOMO) are in a bonding configuration 


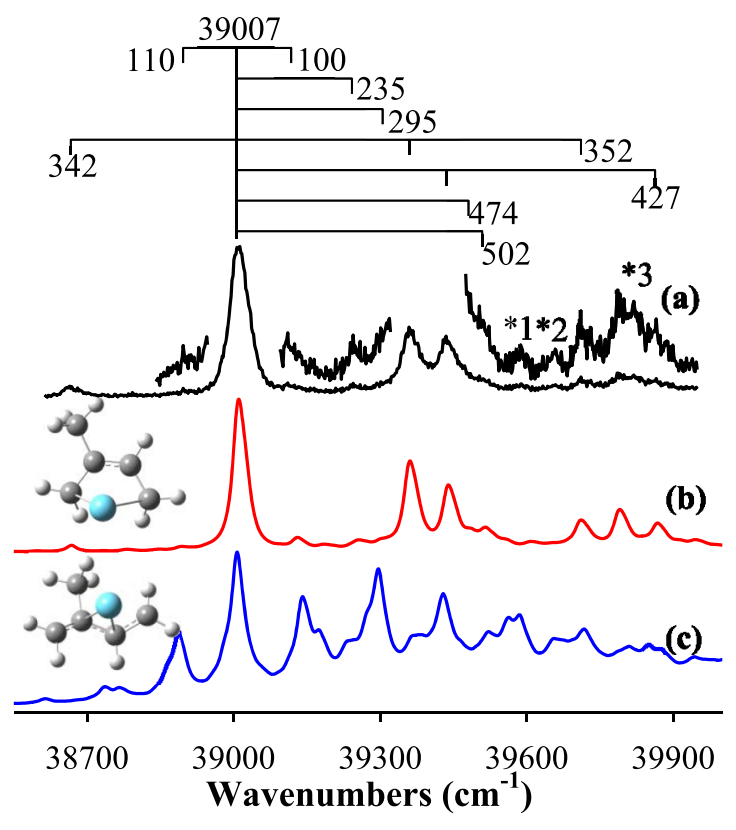

FIG. 2. MATI spectrum of $\mathrm{La}\left(\mathrm{C}_{5} \mathrm{H}_{8}\right)$ produced from the $\mathrm{La}+$ isoprene (a) and simulations of the ${ }^{1} \mathrm{~A} \leftarrow{ }^{2} \mathrm{~A}$ transitions of Iso $\mathrm{A}$ (b) and Iso $\mathrm{B}$ (c) of $\mathrm{La}\left(\mathrm{C}_{5} \mathrm{H}_{8}\right)$ at $200 \mathrm{~K}$. MATI bands labeled "** 1-*3" are combinations bands.

for $\mathrm{C} 1 \mathrm{C} 2$ and $\mathrm{C} 3 \mathrm{C} 4$ but in an antibonding configuration for $\mathrm{C} 2 \mathrm{C} 3$; on the other hand, the four $\mathrm{C} p \pi$ orbitals of the lowest unoccupied molecular orbital (LUMO) are in an antibonding configuration for $\mathrm{C} 1 \mathrm{C} 2$ and $\mathrm{C} 3 \mathrm{C} 4$ but bonding for $\mathrm{C} 2 \mathrm{C} 3$. Metal coordination depletes the diene $\mathrm{p} \pi$ electron density of the HOMO due to donation of the p $\pi$ electrons to an empty La $5 \mathrm{~d} \sigma$ orbital and populates the electron density of the LUMO by back electron donation from a filled $\mathrm{La} 5 \mathrm{~d} \pi$ orbital into the empty diene $\pi^{*}$ orbital. The electron depletion in the HOMO and the electron population in the LUMO will thus have the

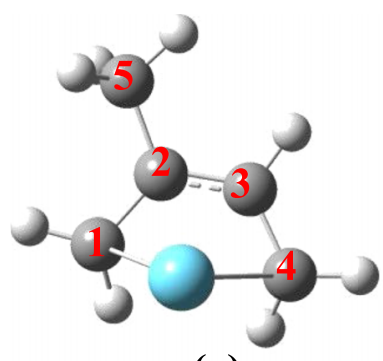

(a)

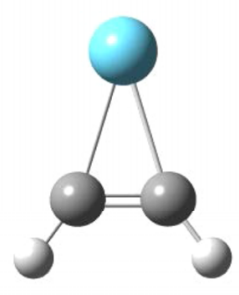

(c)

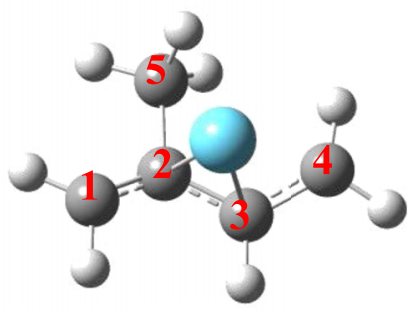

(b)

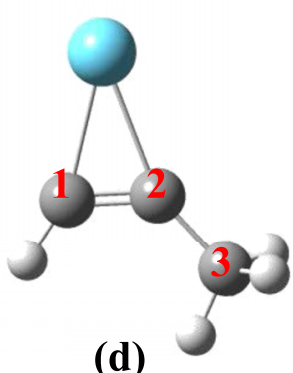

(d)
FIG. 3. Structures of the ground states of Iso A (a) and Iso B (b) of $\mathrm{La}\left(\mathrm{C}_{5} \mathrm{H}_{8}\right)$, $\mathrm{La}\left(\mathrm{C}_{2} \mathrm{H}_{2}\right)$ (c), and $\mathrm{La}\left(\mathrm{C}_{3} \mathrm{H}_{4}\right)$ from the DFT/B3LYP calculations. Relative energies of these species are listed in Table I.
TABLE I. Molecular point groups, electronic states, and relative energies $\left(\mathrm{cm}^{-1}\right)$ of $\mathrm{La}\left(\mathrm{C}_{5} \mathrm{H}_{8}\right), \mathrm{La}\left(\mathrm{C}_{2} \mathrm{H}_{2}\right)$, and $\mathrm{La}\left(\mathrm{C}_{3} \mathrm{H}_{4}\right)$ from the DFT/B3LYP and $\mathrm{CCSD}(\mathrm{T}) / / \mathrm{B} 3 \mathrm{LYP}$ calculations. The energies of $\mathrm{La}\left(\mathrm{C}_{5} \mathrm{H}_{8}\right)$ (Iso B) are relative to those of the $\mathrm{La}\left(\mathrm{C}_{5} \mathrm{H}_{8}\right)$ (Iso A) doublet ground state. All energies include vibrational zero-point energy corrections.

\begin{tabular}{lcccc}
\hline \hline Complex & Point group & State & $\mathrm{E}_{\mathrm{B} 3 \mathrm{LYP}}$ & $\mathrm{E}_{\mathrm{CCSD}(\mathrm{T})}$ \\
\hline $\mathrm{La}\left(\mathrm{C}_{5} \mathrm{H}_{8}\right)$, Iso A & $\mathrm{C}_{1}$ & ${ }^{2} \mathrm{~A}$ & 0 & 0 \\
& $\mathrm{C}_{1}$ & ${ }^{1} \mathrm{~A}$ & 39600 & 38692 \\
$\mathrm{La}\left(\mathrm{C}_{5} \mathrm{H}_{8}\right)$, Iso B & $\mathrm{C}_{1}$ & ${ }^{2} \mathrm{~A}$ & 3559 & 2823 \\
& $\mathrm{C}_{1}$ & ${ }^{1} \mathrm{~A}$ & 44322 & 42320 \\
$\mathrm{La}\left(\mathrm{C}_{2} \mathrm{H}_{2}\right)$ & $\mathrm{C}_{2 \mathrm{v}}$ & ${ }^{2} \mathrm{~A}_{1}$ & 0 & 0 \\
& $\mathrm{C}_{2 \mathrm{v}}$ & ${ }^{1} \mathrm{~A}_{1}$ & 42107 & 40889 \\
$\mathrm{La}\left(\mathrm{C}_{3} \mathrm{H}_{4}\right)$ & $\mathrm{C}_{\mathrm{s}}$ & ${ }^{2} \mathrm{~A}^{\prime}$ & 0 & 0 \\
& $\mathrm{C}_{\mathrm{s}}$ & ${ }^{1} \mathrm{~A}^{\prime}$ & 41214 & 40229 \\
\hline \hline
\end{tabular}

effect of lengthening the $\mathrm{C} 1 \mathrm{C} 2$ and $\mathrm{C} 3 \mathrm{C} 4$ distances and shortening the $\mathrm{C} 2 \mathrm{C} 3$ bond length. Iso $\mathrm{A}$ is a five-membered ring obtained by rotating the $\mathrm{C} 2 \mathrm{C} 3$ bond so that the isoprene carbon backbone is in a cis conformation. It has a significantly shorter $\mathrm{C} 2 \mathrm{C} 3$ distance $(1.388 \AA)$ than $\mathrm{C} 1 \mathrm{C} 2(1.451 \AA)$ or C3C4 (1.455 $\AA$ ) (Table S1 of the supplementary material). Because a five-membered ring is less strained than a threemembered one, Iso A is more stable than Iso B. In both Iso $\mathrm{A}$ and Iso $\mathrm{B}$, the ground electronic state is a doublet with a La $6 s^{1}$-based valence electron configuration. The remaining two electrons that are associated with the isolated $\mathrm{La}$ atom are spin paired in a molecular orbital that is a bonding combination between the La $5 \mathrm{~d} \pi$ orbital and the diene $\pi *$ antibonding orbital. Removal of the La 6 s electron by ionization yields a singlet ion.

The observed MATI spectrum is assigned to the ${ }^{1} \mathrm{~A} \leftarrow{ }^{2} \mathrm{~A}$ transition of Iso A. This assignment is supported by the agreement between the measurement and computation (Table II and Fig. 2). Table II summarizes the measured and calculated AIEs and vibrational frequencies, and Fig. 2 compares the measured spectrum to the simulated vibronic spectrum of the ${ }^{1} \mathrm{~A} \leftarrow{ }^{2} \mathrm{~A}$ transition of Iso $\mathrm{A}$. The $0-0$ transition in the simulation is aligned with the experimental origin band, but the computed vibrational frequencies are unscaled in order to directly compare with the measured spectrum. Based on the spectral simulation, the 352 and $427 \mathrm{~cm}^{-1}$ vibronic progressions are assigned to excitations of a La-ligand symmetric stretch coupled with a $\mathrm{CH}_{3}$ rock $\left(v_{32}{ }^{+}\right)$and a $\mathrm{La}-\mathrm{Cl} / \mathrm{C} 4$ symmetric stretch $\left(v_{30}{ }^{+}\right)$in the ${ }^{1} \mathrm{~A}$ ion. The weak 100, 235, 295, 474 , and $502 \mathrm{~cm}^{-1}$ vibronic bands are attributed to $\mathrm{CH}_{3} \mathrm{wag}$ $\left(v_{36}{ }^{+}\right)$, a $\mathrm{C} 1-\mathrm{La}-\mathrm{C} 4$ bend $\left(v_{34}{ }^{+}\right)$, a $\mathrm{La}-\mathrm{C} 1 / \mathrm{C} 4$ asymmetric stretch $\left(v_{33}{ }^{+}\right)$, a $\mathrm{CH}_{2}$ twist $\left(v_{29}{ }^{+}\right)$around $\mathrm{C} 4$, and another $\mathrm{CH}_{2}$ twist $\left(v_{28}{ }^{+}\right)$around $\mathrm{C} 1$ in the ${ }^{1} \mathrm{~A}$ ion as well. The hot bands at 110 and $342 \mathrm{~cm}^{-1}$ are due to thermal excitations of the $\mathrm{CH}_{3}$ wag $\left(v_{36}\right)$ and La-ligand stretch $\left(v_{32}\right)$ in the ${ }^{2} \mathrm{~A}$ neutral state. We have also considered a possible contribution from the ionization of Iso $\mathrm{B}$, but it is excluded because the simulated transition is not consistent with the observed spectrum in both vibrational frequencies and spectral intensities [Fig. 2(c)]. 
TABLE II. Adiabatic ionization energies (AIEs, $\mathrm{cm}^{-1}$ ) and vibrational frequencies $\left(\mathrm{cm}^{-1}\right)$ of $\mathrm{La}\left(\mathrm{C}_{5} \mathrm{H}_{8}\right.$ ) (Iso A), $\mathrm{La}\left(\mathrm{C}_{2} \mathrm{H}_{2}\right)$, and $\mathrm{La}\left(\mathrm{C}_{3} \mathrm{H}_{4}\right)$ from MATI spectroscopy and DFT/B3LYP and CCSD(T)//B3LYP calculations. $v_{\mathrm{n}}{ }^{+}$and $v_{\mathrm{n}}$ are the vibrational modes in the ionic and neutral states, and the energies in parentheses are from $\operatorname{CCSD}(\mathrm{T}) / / \mathrm{B} 3 \mathrm{LYP}$ calculations.

\begin{tabular}{|c|c|c|c|}
\hline Complex & MATI & B3LYP [CCSD(T)] & Mode description $^{\mathrm{a}}$ \\
\hline \multicolumn{4}{|c|}{$\mathrm{La}\left(\mathrm{C}_{5} \mathrm{H}_{8}\right)$ (Iso A), $\mathrm{C}_{1},{ }^{1} \mathrm{~A} \leftarrow{ }^{2} \mathrm{~A}$} \\
\hline AIE & 39007 & $39600(38692)$ & \\
\hline $\mathrm{v}_{36}^{+} / v_{36}$ & $100 / 110$ & $120 / 118$ & $\mathrm{CH}_{3}$ wag \\
\hline $\mathrm{v}_{34}^{+}$ & 235 & 246 & $\mathrm{C} 1-\mathrm{La}-\mathrm{C} 4$ bend \\
\hline$v_{33}{ }^{+}$ & 295 & 291 & $\mathrm{La}-\mathrm{C} 1 / \mathrm{C} 4$ asymmetric stretch \\
\hline $\mathrm{v}_{32}^{+} / \mathrm{v}_{32}$ & $352 / 342$ & $350 / 339$ & La-ligand stretch and $\mathrm{CH}_{3}$ rock \\
\hline $\mathrm{v}_{30}^{+}$ & 427 & 429 & $\mathrm{La}-\mathrm{C} 1 / \mathrm{C} 4$ symmetric stretch \\
\hline$v_{29}{ }^{+}$ & 474 & 478 & $\mathrm{CH}_{2}$ twist around $\mathrm{C} 4$ \\
\hline$v_{28}{ }^{+}$ & 502 & 506 & $\mathrm{CH}_{2}$ twist around $\mathrm{C} 1$ \\
\hline \multicolumn{4}{|c|}{$\mathrm{La}\left(\mathrm{C}_{2} \mathrm{H}_{2}\right), \mathrm{C}_{2 \mathrm{v}},{ }^{1} \mathrm{~A}_{1} \leftarrow{ }^{2} \mathrm{~A}_{1}$} \\
\hline AIE & 41174 & 42107 (40 889) & \\
\hline $\mathrm{v}_{4}^{+} / \mathrm{v}_{4}$ & $522 / 495$ & $528 / 498$ & La-ligand symmetric stretch \\
\hline $\mathrm{v}_{3}^{+}$ & 806 & 832 & In-plane $\mathrm{C}-\mathrm{H}$ bend \\
\hline \multicolumn{4}{|c|}{$\mathrm{La}\left(\mathrm{C}_{3} \mathrm{H}_{4}\right), \mathrm{C}_{\mathrm{s}},{ }^{1} \mathrm{~A}^{\prime} \leftarrow{ }^{2} \mathrm{~A}^{\prime}$} \\
\hline AIE & 40509 & 41214 (40 229) & \\
\hline $\mathrm{v}_{12}^{+}$ & 224 & 222 & $\mathrm{C} 2-\mathrm{CH}_{3}$ in-plane bend \\
\hline $\mathrm{v}_{11}^{+}$ & 433 & 442 & $\mathrm{La}-\mathrm{C} 2$ stretch and $\mathrm{C} 2-\mathrm{CH}_{3}$ in-plane bend \\
\hline $\mathrm{v}_{10}^{+}$ & 572 & 570 & $\mathrm{La}-\mathrm{C} 1$ stretch and $\mathrm{C} 1-\mathrm{H}$ in-plane bend \\
\hline
\end{tabular}

${ }^{\mathrm{a} S e e ~ F i g . ~} 3$ for the numbering of carbon atoms.

The formation of Iso A is exothermic without energy barriers as illustrated in Fig. 4. The figure presents the DFT/B3LYP computed stationary points, including reactants $\mathrm{La}+$ isoprene, intermediate state IM1, transition state TS1, and the product Iso A in their doublet spin states (except for isoprene which is in a singlet state). Energies of the stationary points

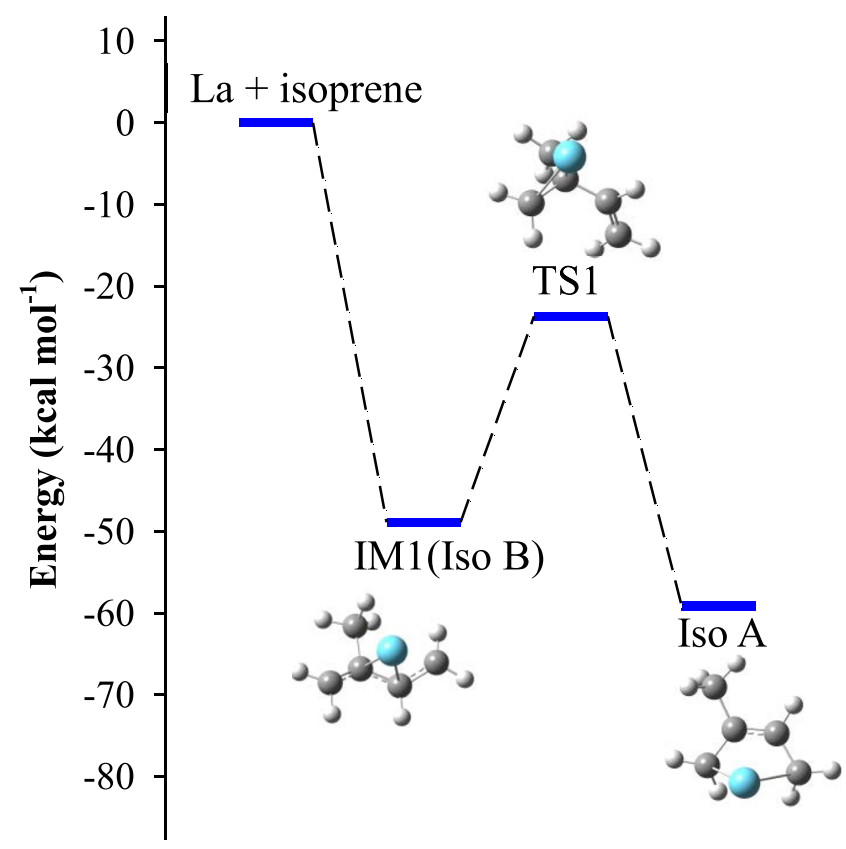

FIG. 4. Reaction pathway and energy profile for the formation of $\mathrm{La}\left(\mathrm{C}_{5} \mathrm{H}_{8}\right)$ (Iso A) from the $\mathrm{La}+$ isoprene reaction at the DFT/B3LYP level, where IM1 and TS1 stand for intermediate and transition states, respectively. are reported in Table S2 of the supplementary material. IM1 is the same species as Iso B formed by La addition to the trans-isoprene and is located at $48.9 \mathrm{kcal} \mathrm{mol}^{-1}$ below the reactants in energy. Isomerization from IM1 to Iso A via TS1 shifts La bonding sites from the middle to terminal carbons and rotates the $\mathrm{C} 2 \mathrm{C} 3$ bond to facilitate the formation of the five-membered metallacycle. The isomerization process is thermodynamically and kinetically favorable because Iso A is more stable than IM1, and TS1 is lower in energy than $\mathrm{La}+$ isoprene. Because of the low energy of TS1, IM1 has tendency to convert to Iso A even though it is predicted to be situated in the valley between the reactants and the transition state. This may explain why IM1 was not detected in our MATI measurements. Recently, we investigated La reactions with 1-butene, 2-butene, and isobutene under similar experimental conditions and found no association product but the dehydrogenated species as the major product in all three reactions. ${ }^{48}$ The comparison of the isoprene and butene reactions under similar conditions suggests that the butadiene molecule is less reactive than the butenes. The lower reactivity of isoprene is largely due to the electron delocalization in the conjugated diene where all backbone carbons are in $\mathrm{sp}^{2}$ hybridization.

\section{C. $\operatorname{La}\left(\mathrm{C}_{2} \mathrm{H}_{2}\right)$}

Even though the number density of $\mathrm{La}\left(\mathrm{C}_{2} \mathrm{H}_{2}\right)$ was very low from the $\mathrm{La}+$ isoprene reaction (Fig. 5), we succeeded in obtaining a sharp MATI spectrum for this species [Fig. 5(a)]. The spectrum exhibits a strong origin band at $41174(5) \mathrm{cm}^{-1}$, 


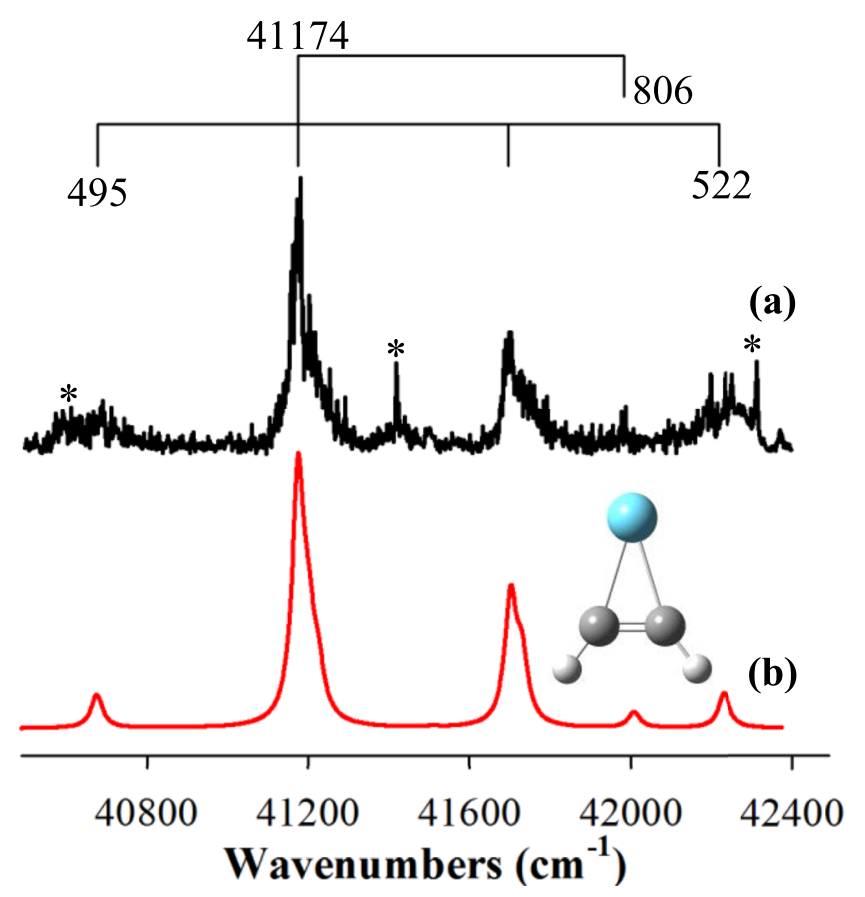

FIG. 5. MATI spectrum of $\mathrm{La}\left(\mathrm{C}_{2} \mathrm{H}_{2}\right)$ produced from the $\mathrm{La}+$ isoprene (a) and simulation of the ${ }^{1} \mathrm{~A}_{1} \leftarrow{ }^{2} \mathrm{~A}_{2}$ transition of $\mathrm{La}\left(\mathrm{C}_{2} \mathrm{H}_{2}\right)$ at $500 \mathrm{~K}$ (b). Sharp lines marked with "**" are due to the interference from $\mathrm{LaO}$.

a $522 \mathrm{~cm}^{-1}$ vibronic progression with up to two quanta and a weak vibronic band at $806 \mathrm{~cm}^{-1}$ to the blue of the origin band, and a hot band at $495 \mathrm{~cm}^{-1}$ to red of the origin band. The origin band and vibronic transition energies are the same as those observed for $\mathrm{La}\left(\mathrm{C}_{2} \mathrm{H}_{2}\right)$ produced in La reactions with ethylene and 1,3-butadiene, ${ }^{42,44}$ though the signal to noise ratios are not as good due to a much lower number density of the species formed in this reaction. The spectrum can easily be assigned to the ${ }^{1} \mathrm{~A}_{1} \leftarrow{ }^{2} \mathrm{~A}_{1}$ transition of lanthanacyclopropene $\left[\mathrm{C}_{2 \mathrm{v}}\right.$, Fig. 3(c)] by comparing with the spectra of $\mathrm{La}\left(\mathrm{C}_{2} \mathrm{H}_{2}\right)$ from the ethylene and 1,3-butadiene reactions and with the simulated spectrum in Fig. 5(b). The transition energy of the origin band, $41174 \mathrm{~cm}^{-1}$, corresponds to the AIE of the species. The $522 \mathrm{~cm}^{-1}$ progression is due to excitations of the $\mathrm{La}-\mathrm{C}_{2} \mathrm{H}_{2}$ symmetric stretch $\left(v_{4}{ }^{+}\right)$and the $806 \mathrm{~cm}^{-1}$ vibronic band to the in-plane $\mathrm{C}-\mathrm{H}$ bend $\left(v_{3}{ }^{+}\right)$in the ${ }^{1} \mathrm{~A}_{1}$ ion, and the $459 \mathrm{~cm}^{-1}$ hot band is assigned to the thermal excitation of the metal-ligand stretch in the ${ }^{2} \mathrm{~A}_{1}$ neutral species (Table II). It is noted that the spectrum of $\mathrm{La}\left(\mathrm{C}_{2} \mathrm{H}_{2}\right)$ is vibrationally much hotter than that of $\mathrm{La}\left(\mathrm{C}_{5} \mathrm{H}_{8}\right)$ because a temperature of $\sim 500 \mathrm{~K}$ is required to simulate the $495 \mathrm{~cm}^{-1}$ hot band of the $\mathrm{La}\left(\mathrm{C}_{2} \mathrm{H}_{2}\right)$ spectrum [Fig. 5(b)], whereas a temperature of $\sim 200 \mathrm{~K}$ is sufficient for simulating the 110 and $342 \mathrm{~cm}^{-1}$ hot bands of the $\mathrm{La}\left(\mathrm{C}_{5} \mathrm{H}_{8}\right)$ Iso A spectrum [Fig. 2(b)]. Different vibrational temperatures for molecules of various sizes seeded in molecular beams are not unusual because the internal modes of the molecules are typically not at thermal equilibria. Generally, smaller molecules with higher vibrational-frequency modes have higher vibrational temperatures than larger molecules with softer vibrational modes. It is also noted that the vibrational temperature of $\mathrm{La}\left(\mathrm{C}_{2} \mathrm{H}_{2}\right)$ formed in the $\mathrm{La}+$ isoprene reaction is considerably higher $(\sim 500 \mathrm{~K})$ than that of $\mathrm{La}\left(\mathrm{C}_{2} \mathrm{H}_{2}\right)$ from the $\mathrm{La}+$ ethylene reaction $(\sim 300 \mathrm{~K}) .{ }^{42}$ This is because $\mathrm{La}\left(\mathrm{C}_{2} \mathrm{H}_{2}\right)$ formed by the
$\mathrm{C}-\mathrm{C}$ bond cleavage of isoprene is strongly exothermic (by $\left.20.6 \mathrm{kcal} \mathrm{mol}^{-1}\right)$ as discussed below, whereas $\mathrm{La}\left(\mathrm{C}_{2} \mathrm{H}_{2}\right)$ formed through the dehydrogenation of ethylene is only weakly exothermic (by $4.7 \mathrm{kcal} \mathrm{mol}^{-1}$ ). A reaction with higher exothermicity is expected to deposit more energy in the internal modes of resultant products than a reaction with lower exothermicity.

A plausible reaction pathway for the formation of $\mathrm{La}\left(\mathrm{C}_{2} \mathrm{H}_{2}\right)$ from the $\mathrm{La}+$ isoprene reaction is illustrated in Fig. 6. It includes $\mathrm{La}$ association and insertion, $\mathrm{H}$ migration, and $\mathrm{C}-\mathrm{C}$ bond cleavage. La addition to form association species Iso $\mathrm{A}$ has been discussed in a previous paragraph. The second step is La insertion into a $\mathrm{C}-\mathrm{H}$ bond of the $\mathrm{CH}_{2}$ group in the $\mathrm{C} 4$ position to form inserted species IM2. Following the $\mathrm{La}-\mathrm{H}$ rotation through TS3, the La-bonded $\mathrm{H}$ is migrated to $\mathrm{C} 3$ and a new lanthanacyclopentene, IM3, is formed with La bonding to both terminal carbon atoms. Although IM3 and Iso A are both five-membered metallacycles, their structures are considerably different, and IM3 is significantly less stable. In IM3, the carbon backbone is non-planar with $\mathrm{C} 3 \mathrm{C} 4$ being a double bond, $\mathrm{C} 1 \mathrm{C} 2$ and $\mathrm{C} 2 \mathrm{C} 3$ being single bonds, and the five-membered ring in a boat-like conformation. On the other hand, the carbon backbone in Iso A is planar with CC distances longer than a $\mathrm{C}=\mathrm{C}$ double bond but shorter than a $\mathrm{C}-\mathrm{C}$ single bond (1.388-1.455 $\AA$ ) and the five-membered ring in a chair-like shape. Like an organic cyclic molecule, the boat-like conformer IM3 is less stable than the chair-like conformer Iso A. Additionally, the delocalized CC bonds are expected to contribute to the stability of Iso A. The last step is the $\mathrm{C} 2 \mathrm{C} 3$ bond cleavage to form $\mathrm{La}\left(\mathrm{C}_{2} \mathrm{H}_{2}\right)+$ propene. The cracking of the $\mathrm{C} 2 \mathrm{C} 3$ bond is facilitated via TS4, where one of the La binding sites shifts from $\mathrm{C} 1$ to $\mathrm{C} 3$ and the $\mathrm{C} 1 \mathrm{C} 2$ bond becomes a double bond. The whole process is exothermic by $20.6 \mathrm{kcal} \mathrm{mol}^{-1}$ and has no barriers above the reactant energies.

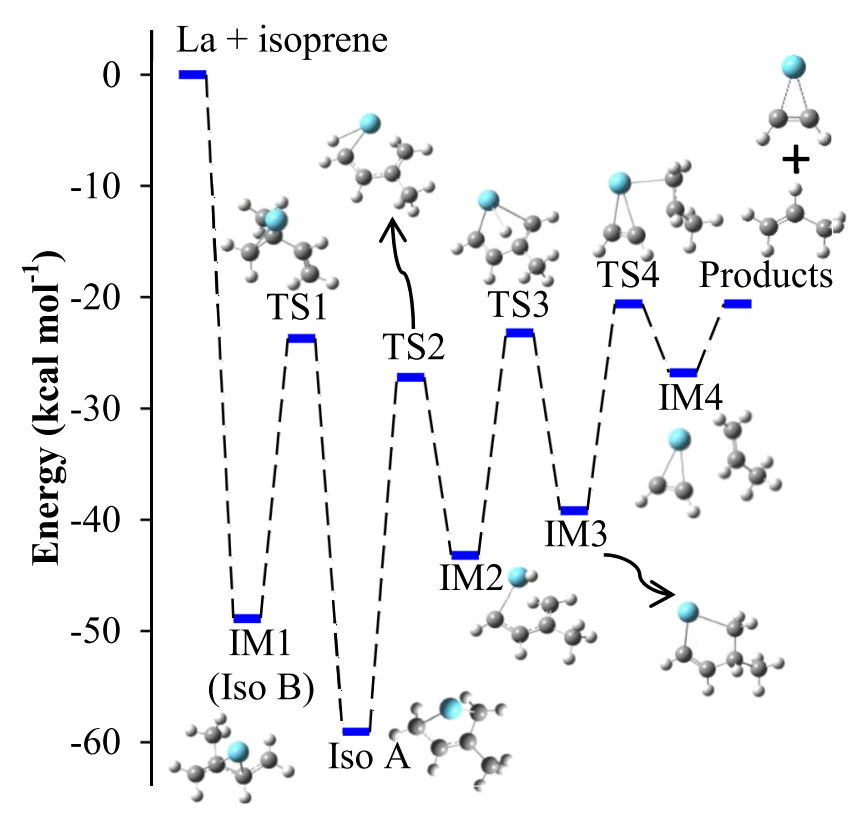

FIG. 6. Reaction pathway and energy profile for the formation of $\mathrm{La}\left(\mathrm{C}_{2} \mathrm{H}_{2}\right)$ from the La + isoprene reaction at the DFT/B3LYP level, where IMn stands for intermediates and TSn stands for transition states. 


\section{D. $\mathrm{La}\left(\mathrm{C}_{3} \mathrm{H}_{4}\right)$}

The MATI spectrum of $\mathrm{La}\left(\mathrm{C}_{3} \mathrm{H}_{4}\right)$ [Fig. 7(a)] exhibits a strong origin band at 40509 (5) $\mathrm{cm}^{-1}$ and weak bands at 224, 433, and $572 \mathrm{~cm}^{-1}$ above the origin band. The spectrum resembles one of the two band systems observed for $\mathrm{La}\left(\mathrm{C}_{3} \mathrm{H}_{4}\right)$ formed through La-mediated dehydrogenation of propene. ${ }^{45}$ In the previous study of the $\mathrm{La}+$ propene reaction, four isomers of $\mathrm{La}\left(\mathrm{C}_{3} \mathrm{H}_{4}\right)$ were considered, two of which, $\mathrm{La}\left(\mathrm{CHCCH}_{3}\right)$ $\left(\mathrm{C}_{\mathrm{s}}\right)$ and $\mathrm{La}\left(\mathrm{CHCHCH}_{2}\right)\left(\mathrm{C}_{1}\right)$, were detected with MATI spectroscopy. By comparing with the MATI spectrum of $\mathrm{La}\left(\mathrm{C}_{3} \mathrm{H}_{4}\right)$ formed in the $\mathrm{La}+$ propene reaction and with the simulated spectrum in Fig. 7(b), the experimental spectrum in Fig. 7(a) is assigned to the ${ }^{1} \mathrm{~A}^{\prime} \leftarrow{ }^{2} \mathrm{~A}^{\prime}$ transition of $\mathrm{La}\left(\mathrm{CHCCH}_{3}\right)$ $\left[\mathrm{C}_{\mathrm{s}}\right.$, Fig. 3(d)]. The 224, 433, and $572 \mathrm{~cm}^{-1}$ vibronic bands are attributed to excitations of a $\mathrm{C} 2-\mathrm{CH}_{3}$ in-plane bend $\left(v_{12}{ }^{+}\right)$, a $\mathrm{La}-\mathrm{C} 2$ stretch coupled with a $\mathrm{C} 2-\mathrm{CH}_{3}$ in-plane bend $\left(v_{11}{ }^{+}\right)$, and a $\mathrm{La}-\mathrm{C} 1$ stretch coupled with $\mathrm{C} 1-\mathrm{H}$ in-plane bend $\left(v_{10}{ }^{+}\right)$of the ${ }^{1} \mathrm{~A}^{\prime}$ ion. The calculated frequencies for the $v_{12}{ }^{+}, v_{11}{ }^{+}$, and $v_{10}{ }^{+}$modes are 222, 442, and $570 \mathrm{~cm}^{-1}$ which are in excellent agreement with the measured values (Table II).

The reaction pathway for the formation of $\mathrm{La}\left(\mathrm{CHCCH}_{3}\right)$ is similar to that of $\mathrm{La}\left(\mathrm{C}_{2} \mathrm{H}_{2}\right)$, which involves $\mathrm{La}$ addition and insertion, $\mathrm{H}$ migration, and $\mathrm{C}-\mathrm{C}$ bond cleavage as illustrated in Fig. 8. However, the $\mathrm{C}-\mathrm{H}$ bond that is activated by $\mathrm{La}$ insertion and the carbon atom to which the $\mathrm{H}$ atom migrates are different between the pathways for the formation of the two species. In the formation of $\mathrm{La}\left(\mathrm{C}_{2} \mathrm{H}_{2}\right)$ (Fig. 6), La inserts into a $\mathrm{C} 4-\mathrm{H}$ bond (IM2) and the La-bonded $\mathrm{H}$ migrates to $\mathrm{C} 2$ (IM3); on the other hand, in the formation of $\mathrm{La}\left(\mathrm{CHCCH}_{3}\right)$ (Fig. 8), La insertion occurs at a $\mathrm{C} 1-\mathrm{H}$ bond (IM5) and the $\mathrm{H}$ migration occurs at C3 (IM6). Nevertheless, because C4-H and $\mathrm{C} 1-\mathrm{H}$ bonds are very similar, energies required for $\mathrm{La}$ insertion into the two $\mathrm{C}-\mathrm{H}$ bonds (TS2 and TS5) are almost

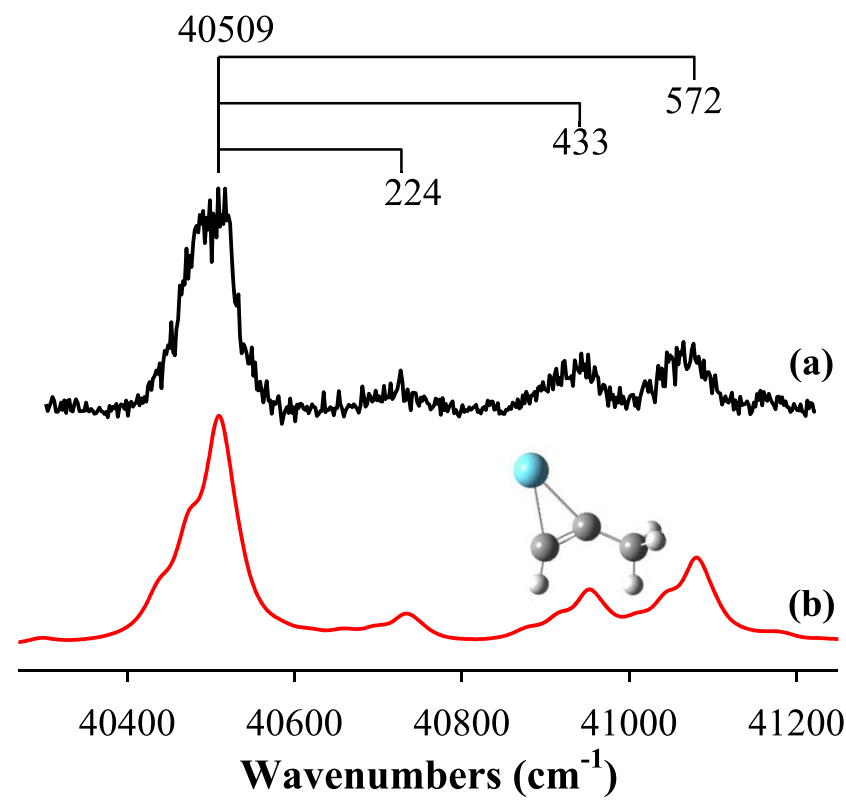

FIG. 7. MATI spectrum of $\mathrm{La}\left(\mathrm{C}_{3} \mathrm{H}_{4}\right)$ produced from the $\mathrm{La}+$ isoprene reaction (a) and simulation of the ${ }^{1} \mathrm{~A}^{\prime} \leftarrow{ }^{2} \mathrm{~A}^{\prime}$ transition of $\mathrm{La}\left(\mathrm{C}_{3} \mathrm{H}_{4}\right)$ at $300 \mathrm{~K}$ (b).

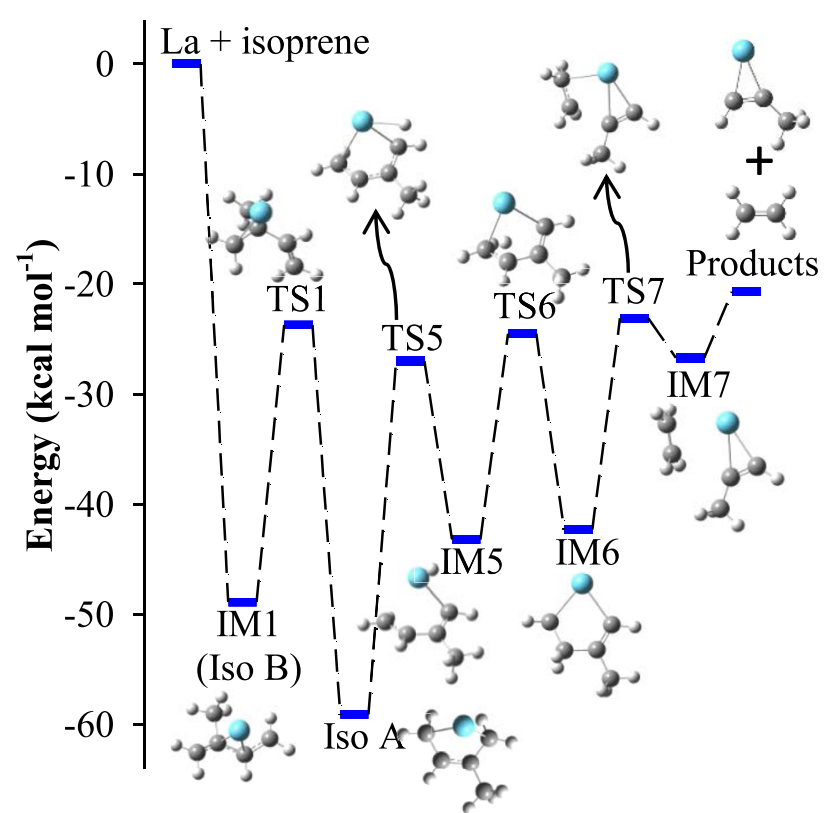

FIG. 8. Reaction pathway and energy profile for the formation of $\mathrm{La}\left(\mathrm{C}_{3} \mathrm{H}_{4}\right)$ from the $\mathrm{La}+$ isoprene reaction at the DFT/B3LYP level, where IMn stands for intermediates and TSn stands for transition states.

identical and so are the energies of the resultant inserted species (IM2 and IM5) (Table S2 of the supplementary material). Likewise, the barriers for the La-bonded $\mathrm{H}$ migrations (TS3 and TS6) are close and so are the resultant five-membered lanthanacycles (IM3 and IM6). The main difference between IM3 and IM6 is the location of the $\mathrm{C}=\mathrm{C}$ double bonds which are $\mathrm{C} 3=\mathrm{C} 4$ in $\mathrm{IM} 3$ and $\mathrm{C} 1=\mathrm{C} 2$ in IM6. The cleaved $\mathrm{C}-\mathrm{C}$ bonds in the formation of both $\mathrm{La}\left(\mathrm{C}_{2} \mathrm{H}_{2}\right)$ and $\mathrm{La}\left(\mathrm{CHCCH}_{3}\right)$ are the same $\mathrm{C} 2-\mathrm{C} 3$ bond. The different products from cracking the same bond are due to the methyl substitution of a $\mathrm{H}$ atom in 1,3-butadiene which yields an asymmetric butadiene with respect to the center point of the $\mathrm{C} 2-\mathrm{C} 3$ single bond.

\section{CONCLUSIONS}

We have reported the MATI spectra and formation of $\mathrm{La}\left(\mathrm{C}_{5} \mathrm{H}_{8}\right), \mathrm{La}\left(\mathrm{C}_{2} \mathrm{H}_{2}\right)$, and $\mathrm{La}\left(\mathrm{C}_{3} \mathrm{H}_{4}\right)$ formed through $\mathrm{La}$ addition and $\mathrm{C}-\mathrm{C}$ bond cleavage of isoprene. The spectra of all three species display a single band system consisting of a strong origin band and several weak vibronic bands. The MATI measurements yield the AIEs and metal-ligand stretching and ligand-based bending frequencies for the three species. Comparing the spectroscopic measurements with quantum chemical calculations allows for the identification of the structures and electronic states of these species. $\mathrm{La}\left(\mathrm{C}_{5} \mathrm{H}_{8}\right)$ is a fivemembered metallacycle, whereas $\mathrm{La}\left(\mathrm{C}_{2} \mathrm{H}_{2}\right)$ and $\mathrm{La}\left(\mathrm{C}_{3} \mathrm{H}_{4}\right)$ are both three-membered rings. The ground state of each species is a doublet state with a La based $6 s^{1}$ electron configuration, and the lowest-energy state of the corresponding ion is a singlet state upon the removal of the La $6 \mathrm{~s}^{1}$ electron. Because of the largely non-bonding nature of the $\mathrm{La} 6 \mathrm{~s}^{1}$ electron, ionization has a small effect on the geometry of the neutral state of each species. Computational reaction pathways show that the formation of $\mathrm{La}\left(\mathrm{C}_{5} \mathrm{H}_{8}\right)$ involves $\mathrm{La}$ addition and isoprene isomerization; the formation of $\mathrm{La}\left(\mathrm{C}_{2} \mathrm{H}_{2}\right)$ and $\mathrm{La}\left(\mathrm{C}_{3} \mathrm{H}_{4}\right)$ each 
consists of $\mathrm{La}$ addition, $\mathrm{La}$ insertion into a $\mathrm{C}-\mathrm{H}$ bond, $\mathrm{H}$ migration, and $\mathrm{C}-\mathrm{C}$ bond cleavage; the formation of the all three species are thermodynamically and kinetically favorable. The observation of both $\mathrm{La}\left(\mathrm{C}_{2} \mathrm{H}_{2}\right)$ and $\mathrm{La}\left(\mathrm{C}_{3} \mathrm{H}_{4}\right)$ confirms that the carbon-carbon bond cracking occurs at the $\mathrm{C} 2-\mathrm{C} 3$ bond of isoprene.

\section{SUPPLEMENTARY MATERIAL}

See supplementary material for the geometries of $\mathrm{La}\left(\mathrm{C}_{5} \mathrm{H}_{8}\right)$ and its singly charged positive ion and the energies of the stationary points along the reaction coordinates for the formation of $\mathrm{La}\left(\mathrm{C}_{5} \mathrm{H}_{8}\right)$ (Iso $\mathrm{A}$ ), $\mathrm{La}\left(\mathrm{C}_{2} \mathrm{H}_{2}\right)$, and $\mathrm{La}\left(\mathrm{C}_{3} \mathrm{H}_{4}\right)$ from the $\mathrm{La}$ atom reaction with isoprene.

\section{ACKNOWLEDGMENTS}

We are grateful for the financial support from the National Science Foundation Division of Chemistry (Chemical Structure, Dynamics, and Mechanisms, Grant No. CHE-1362102). We also acknowledge additional support from the Kentucky Science and Engineering Foundation.

${ }^{1}$ R. S. Walters, T. D. Jaeger, and M. A. Duncan, J. Phys. Chem. A 106, 10482 (2002).

${ }^{2}$ R. S. Walters, E. D. Pillai, P. v. R. Schleyer, and M. A. Duncan, J. Am. Chem. Soc. 127, 17030 (2005).

${ }^{3}$ R. S. Walters, P. V. Schleyer, C. Corminboeuf, and M. A. Duncan, J. Am. Chem. Soc. 127, 1100 (2005).

${ }^{4}$ A. D. Brathwaite, T. B. Ward, R. S. Walters, and M. A. Duncan, J. Phys. Chem. A 119, 5658 (2015).

${ }^{5}$ R. B. Metz, Adv. Chem. Phys. 138, 331 (2008).

${ }^{6}$ G. Altinay, M. Citir, and R. B. Metz, J. Phys. Chem. A 114, 5104 (2010).

${ }^{7}$ G. Altinay and R. B. Metz, J. Am. Soc. Mass Spectrom. 21, 750 (2010).

${ }^{8}$ G. Altinay and R. B. Metz, Int. J. Mass Spectrom. 297, 41 (2010).

${ }^{9}$ M. Citir, G. Altinay, G. Austein-Miller, and R. B. Metz, J. Phys. Chem. A 114, 11322 (2010).

${ }^{10}$ G. Altinay, A. Kocak, J. S. Daluz, and R. B. Metz, J. Chem. Phys. 135, 084311 (2011).

${ }^{11}$ M. Perera, P. Ganssle, and R. B. Metz, Phys. Chem. Chem. Phys. 13, 18347 (2011).

${ }^{12}$ A. Kocak, M. A. Ashraf, and R. B. Metz, J. Phys. Chem. A 119, 9653 (2015).

${ }^{13}$ A. Kocak, Z. Sallese, M. D. Johnston, and R. B. Metz, J. Phys. Chem. A 118, 3253 (2014).

${ }^{14}$ M. A. Ashraf, C. W. Copeland, A. Kocak, A. R. McEnroe, and R. B. Metz, Phys. Chem. Chem. Phys. 17, 25700 (2015).

${ }^{15}$ C. W. Copeland, M. A. Ashraf, E. M. Boyle, and R. B. Metz, J. Phys. Chem. A 121, 2132 (2017).

${ }^{16}$ V. J. F. Lapoutre, B. Redlich, A. F. G. van der Meer, J. Oomens, J. M. Bakker, A. Sweeney, A. Mookherjee, and P. B. Armentrout, J. Phys. Chem. A 117, 4115 (2013).

${ }^{17}$ O. W. Wheeler, M. Salem, A. Gao, J. M. Bakker, and P. B. Armentrout, J. Phys. Chem. A 120, 6216 (2016).

${ }^{18}$ S. R. Miller, T. P. Marcy, E. L. Millam, and D. G. Leopold, J. Am. Chem. Soc. 129, 3482 (2007).

${ }^{19}$ W. Y. Lu, P. D. Kleiber, M. A. Young, and K. H. Yang, J. Chem. Phys. 115, 5823 (2001).

${ }^{20}$ A. S. Gentlman, A. E. Green, D. R. Price, E. M. Cunningham, A. Iskra, and S. R. Mackenzie, Top. Catal. 61, 81 (2018).

${ }^{21}$ G. C. Boles, R. A. Coates, G. Berden, J. Oomens, and P. B. Armentrout, J. Phys. Chem. B 120, 12486 (2016).

${ }^{22}$ G. C. Boles, R. A. Coates, G. Berden, J. Oomens, and P. B. Armentrout, J. Phys. Chem. B 119, 11607 (2015).

${ }^{23}$ G. C. Boles, C. J. Owen, G. Berden, J. Oomens, and P. B. Armentrout, Phys. Chem. Chem. Phys. 19, 12394 (2017).

${ }^{24}$ R. A. Coates, G. C. Boles, C. P. McNary, G. Berden, J. Oomens, and P. B. Armentrout, Phys. Chem. Chem. Phys. 18, 22434 (2016).

${ }^{25}$ R. A. Coates, C. P. McNary, G. C. Boles, G. Berden, J. Oomens, and P. B. Armentrout, Phys. Chem. Chem. Phys. 17, 25799 (2015).
${ }^{26}$ J. A. Maner, D. T. Mauney, and M. A. Duncan, J. Phys. Chem. Lett. 6, 4493 (2015).

${ }^{27}$ G. X. Liu, S. M. Ciborowski, and K. H. Bowen, J. Phys. Chem. A 121, 5817 (2017).

${ }^{28}$ R. B. Wyrwas, B. L. Yoder, J. T. Maze, and C. C. Jarrold, J. Phys. Chem. A 110, 2157 (2006).

${ }^{29}$ S. Xu, J. E. T. Smith, and J. M. Weber, Inorg. Chem. 55, 11937 (2016).

${ }^{30}$ S. Xu, J. E. T. Smith, and J. M. Weber, J. Phys. Chem. A 120, 7650 (2016).

${ }^{31}$ S. Xu, J. E. T. Smith, and J. M. Weber, J. Chem. Phys. 145, 024304 (2016).

${ }^{32}$ S. Xu, J. E. T. Smith, and J. M. Weber, J. Phys. Chem. A 120, 2350 (2016).

${ }^{33}$ J. W. DePalma, P. J. Kelleher, L. C. Tavares, and M. A. Johnson, J. Phys. Chem. Lett. 8, 484 (2017).

${ }^{34}$ M. U. Munshi, S. M. Craig, G. Berden, J. Martens, A. F. DeBlase, D. J. Foreman, S. A. McLuckey, J. Oomens, and M. A. Johnson, J. Phys. Chem. Lett. 8, 5047 (2017).

${ }^{35}$ D. J. Brugh, R. S. Dabell, and M. D. Morse, J. Chem. Phys. 121, 12379 (2004).

${ }^{36}$ M. A. Garcia and M. D. Morse, J. Phys. Chem. A 117, 9860 (2013).

${ }^{37}$ D. J. Brugh and M. D. Morse, J. Chem. Phys. 141, 064304 (2014).

${ }^{38}$ E. L. Johnson and M. D. Morse, Mol. Phys. 113, 2255 (2015).

${ }^{39}$ M. A. Flory, A. J. Apponi, L. N. Zack, and L. M. Ziurys, J. Am. Chem. Soc. 132, 17186 (2010).

${ }^{40}$ D. Hewage, M. Roudjane, W. R. Silva, S. Kumari, and D.-S. Yang, J. Phys. Chem. A 119, 2857 (2015).

${ }^{41}$ D. Hewage, W. R. Silva, W. Cao, and D.-S. Yang, J. Am. Chem. Soc. 138, 2468 (2016).

${ }^{42}$ S. Kumari, W. Cao, Y. Zhang, M. Roudjane, and D.-S. Yang, J. Phys. Chem. A 120, 4482 (2016).

${ }^{43}$ Y. Zhang, M. W. Schmidt, S. Kumari, M. S. Gordon, and D.-S. Yang, J. Phys. Chem. A 120, 6963 (2016).

${ }^{44}$ D. Hewage, W. Cao, J. H. Kim, Y. Wang, Y. Liu, and D.-S. Yang, J. Phys. Chem. A 121, 1233 (2017).

${ }^{45}$ S. Kumari, W. Cao, D. Hewage, R. Silva, and D.-S. Yang, J. Chem. Phys. 146, 074305 (2017).

${ }^{46}$ D. Hewage, W. Cao, S. Kumari, R. Silva, T. H. Li, and D.-S. Yang, J. Chem. Phys. 146, 184304 (2017).

${ }^{47}$ W. Cao, D. Hewage, and D.-S. Yang, J. Chem. Phys. 147, 064303 (2017).

${ }^{48}$ W. Cao, D. Hewage, and D.-S. Yang, J. Chem. Phys. 148, 044312 (2018).

${ }^{49}$ J. Huang, Z. Liu, D. Cui, and X. Liu, ChemCatChem 10, 42 (2018).

${ }^{50}$ V. Baranov, H. Becker, and D. K. Bohme, J. Phys. Chem. A 101, 5137 (1997).

${ }^{51}$ P. I. Surya, D. R. A. Ranatunga, and B. S. Freiser, J. Am. Chem. Soc. 119, 3351 (1997).

${ }^{52} \mathrm{P}$. Mourgues, A. Ferhati, T. B. McMahon, and G. Ohanessian, Organometallics 16, 210 (1997).

${ }^{53}$ K. A. Zemski, R. C. Bell, and A. W. Castleman, Int. J. Mass. Spetrom. 184, 119 (1999).

${ }^{54}$ K. A. Zemski, R. C. Bell, and A. W. Castleman, Jr., J. Phys. Chem. A 104, $5732(2000)$

${ }^{55}$ R. C. Bell, K. A. Zemski, K. P. Kerns, H. T. Deng, and A. W. Castleman, J. Phys. Chem. A 102, 1733 (1998).

${ }^{56}$ F. Dong, S. Heinbuch, Y. Xie, E. R. Bernstein, J. J. Rocca, Z.-C. Wang, X.-L. Ding, and S.-G. He, J. Am. Chem. Soc. 131, 1057 (2009).

${ }^{57}$ B. R. Sohnlein, S. G. Li, J. F. Fuller, and D.-S. Yang, J. Chem. Phys. 123, 014318 (2005).

${ }^{58}$ C. E. Moore, Atomic Energy Levels (National Bureau of Standards, Washington, DC, 1971).

${ }^{59}$ M. A. Duncan, T. G. Dietz, and R. E. Smalley, J. Chem. Phys. 75, 2118 (1981).

${ }^{60}$ D.-S. Yang, J. Phys. Chem. Lett. 2, 25 (2011).

${ }^{61}$ T. H. Dunning, Jr., J. Chem. Phys. 90, 1007 (1989).

${ }^{62}$ W. A. de Jong, R. J. Harrison, and D. A. Dixon, J. Chem. Phys. 114, 48 (2001).

${ }^{63}$ Q. Lu and K. A. Peterson, J. Chem. Phys. 145, 054111 (2016).

${ }^{64}$ M. J. Frish, G. W. Trucks, H. B. Schlegel, G. E. Scuseria, M. A. Robb, J. R. Cheeseman, G. Scalmani, V. Barone, B. Mennucci, G. A. Petersson, H. Nakatsuji, M. Caricato, X. Li, H. P. Hratchian, A. F. Izmaylov, J. Bloino, and G. Zheng, Gaussian 09, Revision A.01, Gaussian, Inc., Wallingford, CT, 2009.

${ }^{65}$ H.-J. Werner, P. J. Knowles, G. Knizia, F. R. Manby, M. Schutz, P. Celani, T. Korona, R. Lindh, A. Mitrushenkov, G. Rauhut, K. R. Shamasundar, T. B. Adler, R. D. Amos, A. Bernhardsson, A. Berning, D. L. Cooper, M. J. O. Deegan, A. J. Dobbyn, F. Eckert, E. Goll, C. Hampel, A. Hesselmann, G. Hetzer, T. Hre-nar, G. Jansen, C. Koppl, Y. Liu, A. W. Lloyd, 
R. A. Mata, A. J. May, S. J. McNicholas, W. Meyer, M. E. Mura, A. Nicklass, D. P. O’Neill, P. Palmieri, K. Pfluger, R. Pitzer, M. Reiher, T. Shiozaki, H. Stoll, A. J. Stone, R. Tarroni, T. Thorsteinsson, M. Wang, and A. Wolf, MoLPRo, version 2010.1, a package of ab initio programs, 2010, see http://www.molpro.net.
${ }^{66} \mathrm{~S}$. Li, "Threshold photoionization and ZEKE photoelectron spectroscopy of metal complexes," Ph.D. thesis, University of Kentucky, 2004.

${ }^{67}$ E. V. Doktorov, I. A. Malkin, and V. I. Man'ko, J. Mol. Spectrosc. 64, 302 (1977).

${ }^{68}$ F. Duschinsky, Acta Physicochim. 7, 551 (1937). 